\title{
Mother-young relationships in captive ungulates: variability and clustering
}

\author{
KATHERINE RALLS*, KARL KRANZ* \& BARBARA LUNDRIGAN† \\ *Department of Zoological Research, National Zoological Park, Smithsonian Institution, Washington, D.C. \\ 20008, U.S.A. \\ $\dagger$ Museum of Zoology, University of Michigan, Ann Arbor, Michigan 48109, U.S.A.
}

\begin{abstract}
We recorded four measures of mother-young association and the percentage of time the young spent lying during the first week after birth for 59 mother-young pairs belonging to 22 species and seven families of ungulates. The measures of mother-young association were positively correlated with each other and negatively correlated with the percentage of time the young spent lying. Three cluster analyses, based on various combinations of measures, separated the bovids into two groups recognizable as 'followers' and 'hiders'. When the data on all 22 species were considered, five consistent species groups occurred in the three cluster analyses. The traditional follower-hider dichotomy provides a rough characterization of mother-young relationships in many ungulates, but does not adequately describe the behavioural variation present. By using standardized quantitative measures, we were able to characterize this variation and to establish a framework for future study.
\end{abstract}

Studies of ungulate mother-young relationships have led to the generalization that the young may be roughly classified into two groups: those that initially stay close to their mothers and those that spend the first part of their lives at some distance from their mothers, often concealed in vegetation. These striking behavioural differences are apparent to anyone who has observed a variety of ungulate species; the first formal descriptions appeared during the 1960s (Fraser 1968; Talbot et al. 1965; Walther 1961, 1964, 1966). Walther (1965) termed these groups 'Nachfolge Typus' (follower-type) and 'Abliege-Typus' (lying-apart-type), respectively. In English the two behavioural patterns are usually referred to as 'following' and 'hiding' (Lent 1974; Leuthold 1977).

The observations on which Walther based the behavioural dichotomy were made on several species of African antelopes, and his subsequent work (summarized in Walther 1979) also concentrated on bovids. However, the concepts have been applied to ungulates in other families such as cervids and equids (Lent 1974; Leuthold 1977).

There are a number of hypotheses in the literature regarding the adaptive significance of following and hiding. We use the terms 'following' and 'hiding' for the two types of spatial relationship without implications as to the behavioural mechanisms by which these relationships are maintained. Following has been viewed as a strategy for avoiding predators in open habitat (Lent 1974; Estes 1976) and is often associated with migratory habits and/or defence of the young against predators. Hiding is thought to reduce predation risk in closed habitats (Lent 1974; Estes 1976), but may also protect young from intraspecific aggression (Lent 1974) or competition (Murdock et al. 1983) and help them to conserve energy and body water (Langman 1977).

Although the terms 'hider' and 'follower' are frequently used in the ungulate literature, the adequacy of this classification system has never been evaluated. The collections of the National Zoological Park (NZP), Washington, D.C., and the Metropolitan Toronto Zoo (MTZ), Scarborough, Ontario, provided us with an opportunity to compare a wide range of species using standardized methods. The broad species-typical patterns of the mother-young relationship are known to be retained in captivity; indeed, the original descriptions of the follower and hider groups were largely based on observations of captive animals (Walther 1964, 1965, 1966).

The principal goals of our study were to assess the adequacy of the follower-hider model, measure the variability among species reportedly belonging to each category and determine the extent to which intermediate types might exist, both within the Bovidae and across ungulates as a whole. 
Table I. Number of mother-young pairs observed and percentage observation time visible for each species

\begin{tabular}{|c|c|c|}
\hline Taxon & $\begin{array}{c}\text { Number of } \\
\text { pairs } \\
\text { observed }\end{array}$ & $\begin{array}{l}\text { Percentage } \\
\text { time } \\
\text { visible }\end{array}$ \\
\hline \multicolumn{3}{|l|}{ Equidae } \\
\hline $\begin{array}{l}\text { Equus burchelli } \\
\text { (zebra) }\end{array}$ & 3 & 97 \\
\hline $\begin{array}{l}\text { Equus hemionus } \\
\text { (onager) }\end{array}$ & 4 & 93 \\
\hline $\begin{array}{l}\text { Tapiridae } \\
\text { Tapirus terrestris } \\
\text { (tapir) }\end{array}$ & 1 & 100 \\
\hline $\begin{array}{l}\text { Hippopotamidae } \\
\text { Hippopotamus amphibius } \\
\text { (Nile hippopotamus) }\end{array}$ & 2 & 98 \\
\hline $\begin{array}{l}\text { Choeropsis liberiensis } \\
\text { (pygmy hippopotamus) }\end{array}$ & 1 & 95 \\
\hline $\begin{array}{l}\text { Camelidae } \\
\text { Camelus bactrianus } \\
\text { (bactrian camel) }\end{array}$ & 2 & 100 \\
\hline $\begin{array}{l}\text { Cervidae } \\
\text { Muntiacus reevesi } \\
\text { (muntjac) }\end{array}$ & 1 & 50 \\
\hline $\begin{array}{l}\text { Elaphurus davidianus } \\
\text { (Père David's deer) }\end{array}$ & 1 & 100 \\
\hline $\begin{array}{l}\text { Rangifer tarandus } \\
\text { (reindeer) }\end{array}$ & 5 & 91 \\
\hline $\begin{array}{l}\text { Giraffidae } \\
\text { Giraffa camelopardalis } \\
\text { (giraffe) }\end{array}$ & 3 & 9.3 \\
\hline $\begin{array}{l}\text { Bovidae } \\
\text { Tragelaphus eurvcerus }\end{array}$ & 2 & 100 \\
\hline (bongo) & & \\
\hline $\begin{array}{l}\text { Bison bison } \\
\text { (wood bison) }\end{array}$ & 3 & 90 \\
\hline $\begin{array}{l}\text { Kobus ellipsiprymnus } \\
\text { (waterbuck) }\end{array}$ & 1 & 50 \\
\hline $\begin{array}{l}\text { Hippoptragus niger } \\
\text { (sable) }\end{array}$ & 4 & 74 \\
\hline $\begin{array}{l}\text { Orvx dammah } \\
\text { (scimitar-horned oryx) }\end{array}$ & 6 & 84 \\
\hline $\begin{array}{l}\text { Connochaetes taurinus } \\
\text { (wildebeest) }\end{array}$ & 3 & 98 \\
\hline $\begin{array}{l}\text { Madoqua kirki } \\
\text { (dik-dik) }\end{array}$ & 1 & 67 \\
\hline $\begin{array}{l}\text { Gazella dorcas } \\
\text { (Dorcas gazelle) }\end{array}$ & 7 & 94 \\
\hline $\begin{array}{l}\text { Gazella dama } \\
\text { (dama gazelle) }\end{array}$ & I & 99 \\
\hline $\begin{array}{l}\text { Hemitragus jemlahicus } \\
\text { (Himalayan tahr) }\end{array}$ & 3 & 78 \\
\hline $\begin{array}{l}\text { Capra ibex } \\
\text { (Kuban ibex) }\end{array}$ & 3 & 82 \\
\hline $\begin{array}{l}\text { Ammotragus lervia } \\
\text { (aoudad) }\end{array}$ & 2 & 89 \\
\hline
\end{tabular}




\section{METHODS}

Fifty-nine mother-young pairs representing 22 species and seven families were observed for a total of over $1400 \mathrm{~h}$ between 1977 and 1982 (Table I). Most pairs were observed either at NZP or the NZP's Conservation and Research Center (CRC) in Front Royal, Virginia. The bison (Bison bison), tahr (Hemitragus jemlahicus), aoudad (Ammotragus lervia) and ibex (Capra ibex) were observed at MTZ and the waterbuck (Kobus ellipsiprymnus) at King's Dominion in Doswell, Virginia. Enclosure sizes and the number of conspecifics present with the mother-young pairs varied. The social groupings in captivity resembled those in the wild. Monogamous species such as dik-dik (Madoqua kirki) (Hendrichs \& Hendrichs 1971) were kept in pairs and gregarious species, except for the Nile hippopotamus (Hippopotamus amphibius), were kept in herds.

Each pair was observed for at least 6 weeks. However, we considered only first week data in the analysis reported here because hiding behaviour in some species may begin to decrease in the second week after birth (Walther 1979). First week data were collected by 15 experienced observers, each assigned to one or more mother-young pairs. Although differences between observers may have influenced our results, we believe this was not a serious problem. Inter-observer differences should have been smaller in the first week, when experienced observers collected data, than in subsequent weeks, when a much larger group of volunteers made many of the observations. Our analysis of the mean weekly coefficients of variation over the entire 8-week study period showed that even these were not related to the number of observers contributing data for a particular species (Ralls et al. 1983).

An attempt was made to observe each pair for $1 \mathrm{~h}$ per day, three or more times during week 1 , but scheduled observations were occasionally missed. Most observations were made during periods when animals were usually most active, either in the morning, between 0800 and 1000 hours, or in late afternoon between 1600 and 1800 hours. Fifty-six of the young were singletons and three were twins (one aoudad and two ibex). In the latter cases, one twin was chosen for observation throughout the study. Data were recorded on a simple check sheet which was revised several times to eliminate measures on which observers could not reach it high level of agreement (at least $90 \%$ ).

The most fundamental behavioural difference between followers and hiders is usually considered to be the degree of association between mother and young during the first days after birth. We measured degree of association in four ways. Two of our measures, the percentage of 1 -min intervals the mother and young were in contact (Contact) and the percentage of 1-min intervals the mother and young were within 1 mother-length of one another $(<1 \mathrm{ML})$, were suggested by Lent's (1974) model contrasting the behaviour of followers and hiders. We considered mother and young to be in contact when the two were lying or standing with any part of their bodies touching. Recording the average distance between mother and young (as suggested by Lent's model) proved impractical because observer estimates of absolute distance varied widely. Thus, we recorded distance in 'motherlengths', a different absolute value for each species.

Although he presented no quantitative data, Walther (1979) suggested that hider and follower species could be easily distinguished by the distance between mother and young while both animals were lying. Our third measure, number of minutes mother and young both lying within 1 motherlength/total minutes both mother and young lying (Walther's measure), was based on this suggestion.

The final measure of association, the percentage of 1-min intervals the mother was the closest animal to her young (MCA), was designed to estimate the extent to which a mother was the nearest neighbour to her young. MCA was corrected for the number of animals in the enclosure [(observed \%MCA-expected \%MCA)/(100expected $\% \mathrm{MCA}) \times 100]$. This index (MCA index) was scaled so that it would have the same range $(0-$ $100)$ as the other measures.

Focal mother-young pair sampling was combined with instantaneous sampling at the end of each minute for all measures except Contact. Because some observers had difficulty ignoring interesting behaviours such as nursing or sniffing. we scored Contact on a $1-0$ basis regardless of where in the 1-min interval it occurred. Each measure was expressed as the percentage of $1-\mathrm{min}$ intervals during which it was recorded, e.g. $<1$ $\mathrm{ML}=$ (number of minutes mother and young were recorded as within one mother-length of each other/total minutes during which data were recorded) $\times 100$. We used the number of minutes 
during which data were recorded as a denominator, rather than the minutes of observation time, because the mother and young were not always visible for the entire observation period (Table I).

We performed cluster analyses (after Sokal 1961) to obtain a graphic representation of the relationships among species. Three cluster analyses were performed, each employing a different combination of behavioural measures. The three combinations of measures were: (1) only the measures of mother-young association suggested by the work of Lent (1974) and Walther (1979), i.e. <1 ML. Walther's measure and Contact; (2) all four measures of mother-young association, i.e. the three above plus MCA index; and (3) these four measures plus the percentage of $1-$ min intervals the young spent lying (Young Lying).

The clustering procedure required that we estimate missing data points. Data on one measure were missing for eight species and on three measures for one species. The two most common reasons for missing data were: (1) the MCA index could not be calculated because the mother and young were the only animals present in the enclosure, and (2) Walther's measure could not be calculated because mother and young were never observed both lying. Estimates for missing data points were calculated by a least squares regression analysis using the Spearman's rank correlation of coefficients between the four measures of motheryoung association described above. Estimates of over 100 were recorded as 100 .

A computer program in the Michigan Interactive Data Analysis System (MIDAS) was used to obtain the cluster diagrams. This program calculates Euclidean distances between species and uses an averaging technique to form clusters in which species (and groups of species) linked at low distance values are more similar on the measures used than those linked at high distance values. The cophenetic correlation (a measure of agreement between the similarity values implied by the den-

Table II. Means and standard deviations for five behavioural measures recorded during the first week after birth

\begin{tabular}{|c|c|c|c|c|c|}
\hline Species & $\begin{array}{c}<1 \mathrm{ML} \\
\text { mean }(\mathrm{SD})\end{array}$ & $\begin{array}{l}\text { Walther"s } \\
\text { measure } \\
\text { mean (SD) }\end{array}$ & $\begin{array}{l}\text { Contact } \\
\text { mean (SD) }\end{array}$ & $\begin{array}{l}\text { MCA index } \\
\text { mean (SD) }\end{array}$ & $\begin{array}{c}\text { Young } \\
\text { Lying } \\
\text { mean (SD) }\end{array}$ \\
\hline Hippopotamust & 100 & 100 & 88 & 100 & 61 \\
\hline Pygmy hippopotamus $\dagger$ & 100 & 100 & $\underline{58}$ & 100 & 91 \\
\hline Camel & 99 & $\overline{100}$ & 32 & $\overline{100}$ & 58 \\
\hline Onager & $98(3)$ & $100(-)$ & $36(2)$ & $\overline{100}(0)$ & $32(11)$ \\
\hline Zebra & $94(2)$ & $100(-)$ & $25(13)$ & $99(2)$ & $10(11)$ \\
\hline Wildebeest* & $92(11)$ & $\overline{100}(0)$ & $20(11)$ & $85(7)$ & $63(20)$ \\
\hline Reindeer & $76(13)$ & $94(48)$ & $32(16)$ & $95(5)$ & $76(16)$ \\
\hline Tapir & 75 & 100 & 18 & 91 & 73 \\
\hline Bison* & $72(19)$ & $72(43)$ & $20(6)$ & $73(2)$ & $82(12)$ \\
\hline Tahr* & $64(13)$ & $71(43)$ & $36(11)$ & $69(6)$ & $64(9)$ \\
\hline Aoudad* & 64 & 100 & 32 & 65 & 73 \\
\hline Giraffe & $56(20)$ & $58(-)$ & $8(8)$ & $61 \quad(0)$ & $18(5)$ \\
\hline Ibex* & $54(12)$ & $\overline{65}(17)$ & $40(16)$ & $67(7)$ & $70(26)$ \\
\hline Bongo* & 45 & 46 & 8 & 85 & 74 \\
\hline Oryx* & $35(30)$ & $32(41)$ & $12(7)$ & $69(31)$ & $84(13)$ \\
\hline Père David's deer & 27 & 0 & 5 & 41 & 79 \\
\hline Dama gazelle* & 24 & 0 & 2 & 68 & 69 \\
\hline Dik-dik* & 19 & 0 & 1 & 0 & 85 \\
\hline Dorcas gazelle* & $12(4)$ & $0(0)$ & $4(4)$ & $45(18)$ & $82(8)$ \\
\hline Sable* & $3(5)$ & $0(0)$ & $0(0)$ & $29(60)$ & $99(2)$ \\
\hline Waterbuck* & 0 & 0 & 0 & 7 & 100 \\
\hline Muntjac & 0 & 0 & 0 & $\overline{3}$ & 95 \\
\hline
\end{tabular}

Underlined values are estimates for missing data.

Standard deviations were calculated only when three or more pairs were observed.

* Members of the family Bovidae.

† 'Inactive' rather than 'lying' scored. 
Table III. Spearman's rank correlation coefficients between five behavioural measures recorded during the first week after birth

\begin{tabular}{crrrr}
\hline Measures & \multicolumn{1}{c}{1} & \multicolumn{1}{c}{2} & \multicolumn{1}{c}{3} & 4 \\
\hline 1 & & & & \\
2 & 0.9401 & & & \\
3 & 0.8659 & 0.8286 & & \\
4 & 0.9221 & 0.8484 & 0.7795 & \\
5 & -0.6256 & -0.5399 & -0.5375 & -0.5766 \\
\hline
\end{tabular}

Measures: (1) < I ML; (2) Walther's measure; (3) Contact; (4) MCA index; and (5) Young Lying.

All values are significant at $P<0 \cdot 01$.

Table IV. Spearman's rank correlation coefficients between five behavioural measures recorded during the first week after birth for bovids and non-bovids

\begin{tabular}{ccccc}
\hline \multicolumn{1}{c}{ Measures } & 1 & 2 & 3 & 4 \\
\hline Bovids & & & & \\
1 & & & & \\
2 & $0.9458^{* *}$ & & & \\
3 & $0.8409^{* *}$ & $0.8427^{* *}$ & & \\
4 & $0.7587^{* *}$ & $0.6678^{*}$ & 0.5542 & $-0.6311^{*}$ \\
5 & $-0.7411^{* *}$ & -0.5664 & $-0.7063^{*}$ & \\
Non-bovids & & & & \\
1 & & & & \\
2 & $0.8515^{* *}$ & & & \\
3 & $0.9576^{* *}$ & $0.7879^{* *}$ & $0.9394^{* *}$ & -0.2970 \\
4 & $0.9727^{* *}$ & $0.8788^{* *}$ & -0.1788 & \\
5 & -0.2333 & -0.2727 & & \\
\hline
\end{tabular}

(1) < I ML; (2) Walther's measure; (3) Contact; (4) MCA index; and (5) Young Lying.

* $P<0.05$; $^{* *} P<0.01$.

drogram and those of the original similarity matrix) was used to evaluate clustering performance.

\section{RESULTS}

Means and standard deviations for five behavioural measures recorded during the first week after birth for the 22 species are given in Table II. Correlation coefficients between the five measures of mother-young behaviour are shown in Table III. The four measures of mother--young association are positively correlated with one another $(P<0.01)$ and negatively correlated with the percentage of time the young spent lying $(P<0.01)$. These correlation coefficients were also calculated for bovids and non-bovids separately. The result- ing matrices (Table IV) reflect the same trends as shown in Table III. However, the correlation coefficients between Young Lying and the four measures of mother-young association are lower and non-significant for the non-bovids.

\section{Relationships Among Species: Walther's Measure}

In order to evaluate Walther's idea that follower and hider species can be distinguished by the distance between mother and young while both animals are lying, we first examined relationships among the bovid species in terms of Walther's measure. It clearly separates wildebeest (Connochaetes taurinus) and aoudad, which scored $100 \%$, from dama gazelle (Gazella dama), Dorcas gazelle (Gazella dorcas), dik-dik (Madoqua kirki), sable 


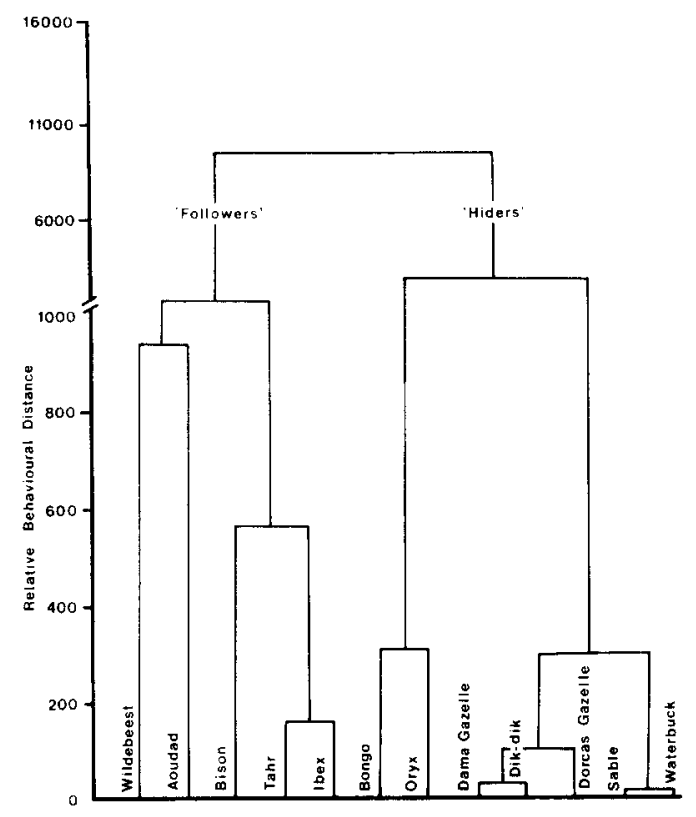

Figure 1. Cluster analysis of data for bovids using $<1$ ML, Walther's measure and Contact. Cophenetic correlation $=0.7491$.

(Hippotragus niger) and waterbuck, all of which scored $0 \%$ (Table II). However, five other bovids, bison, tahr, ibex, bongo (Tragelaphus eurycerus) and oryx (Oryx dammah), had intermediate scores (range $32-72 \%$ ).

Walther's measure was much less satisfactory for the non-bovid species. Adults of the two hippopotamus species (Nile hippopotamus and pygmy hippopotamus, Choeropsis liberiensis) rarely, if ever, lie down and we therefore had to base Walther's measure on the percentage of intervals both mother and young were inactive. Furthermore, mother and young were never both lying during the first week in four other species, giraffe (Giraffa camelopardalis), onager (Equus hemionus), zebra (Equus burchelli) and muntjac (Muntiacus reevesi). Walther's measure had to be estimated from our other measures in these cases. Walther's measure separates the remaining non-bovids into two groups, camel (Camelus bactrianus), tapir (Tapirus terrestris) and reindeer (Rangifer tarandus) which scored $100 \%, 100 \%$ and $94 \%$, respectively and Père David's deer (Elaphurus davidianus) which scored $0_{\%}^{\circ}$.

\section{Relationships Among Species: Cluster Analysis}

Clustering procedures impose a hierarchical structure on species and species groups so it is necessary to consider whether the method produces an unacceptable distortion of the data. The reasonably high cophenetic correlations for our analyses $(0.7416-0.7571)$ indicate that the cluster diagrams (Figs 1,2) represent an adequate summary of actual relationships between species. The cluster analysis based on $<1 \mathrm{ML}$, Walther's measure and Contact separates the bovids into two groups (Fig. 1). The smaller group consists of wildebeest, an African antelope, bison (tribe Bovini), and three Caprini: tahr, ibex and aoudad. The larger group consists entirely of African antelopes: bongo, oryx, dama and Dorcas gazelles, dik-dik, sable and waterbuck. Cluster analyses using the additional measures. MCA index and both MCA index and Young Lying, produce the same two major groups (not shown).

Five consistent species groups can be distinguished in the all species cluster diagrams (Fig. $2 a, b, c)$. The first group includes Nile hippopotamus and pygmy hippopotamus, which are always associated with one another and separated from the remaining species. The second group contains camel, wildebeest, reindeer, and tapir. which are always together although other members of the cluster vary. The third group includes the bison. tahr and ibex. This group appears either in association with the group 2 species (Fig. 2a. c) or as part of a large 'intermediate' cluster (Fig. 2b). Group 4 includes five bovids and two cervids: Dorcas and dama gazelles, dik-dik, waterbuck, sable, muntjac and Père David's deer. Group 5 contains bongo and oryx; these two species are either loosely associated with the bovids and cervids of group 4 (Fig. 2a). in the 'intermediate' cluster (Fig. 2b). or loosely associated with the large cluster containing groups 1.2 and 3 (Fig. 2c)

\section{DISCUSSION}

\section{Methodological Problems}

Many of our sample sizes were small, either in terms of the number of pairs per species, the total time during which data were recorded, or both. but this did not appear to have a marked effect on the results. Data for the species with the smallest sample sizes (muntjac, waterbuck and dik-dik) resembled those for other hider species with larger 


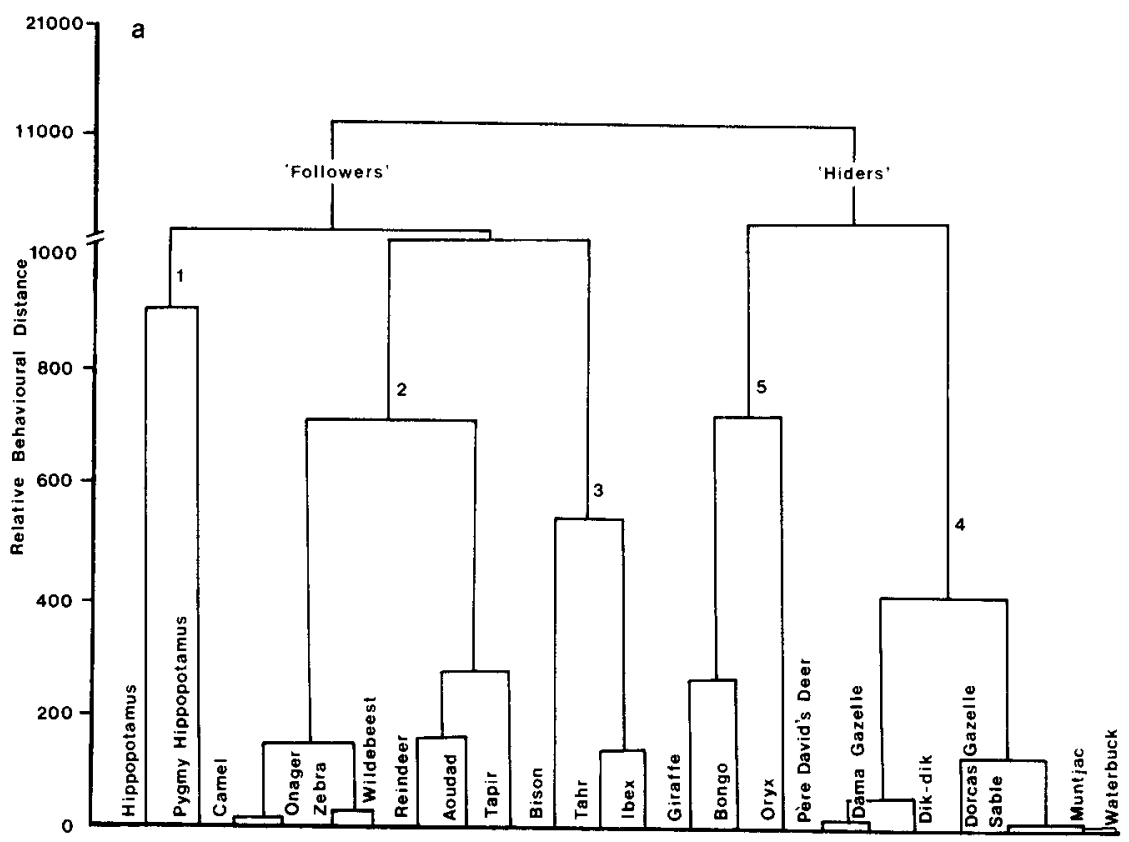

Figure 2a.

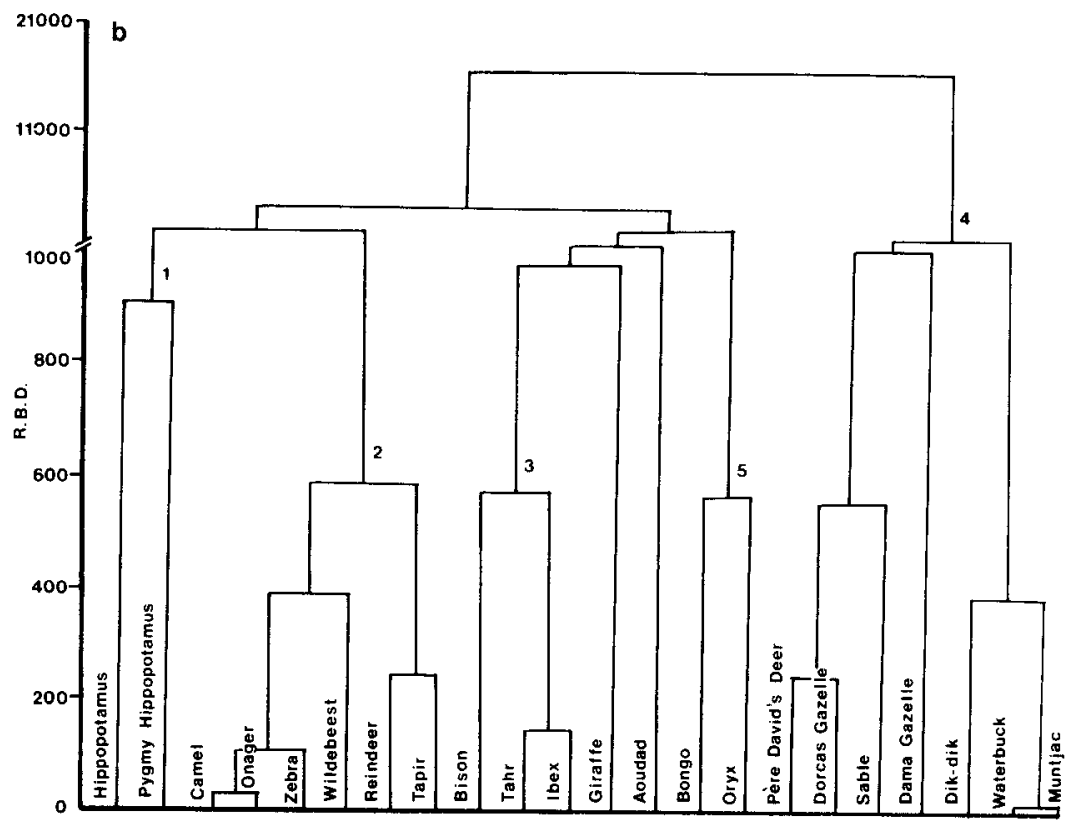

Figure 2b. 


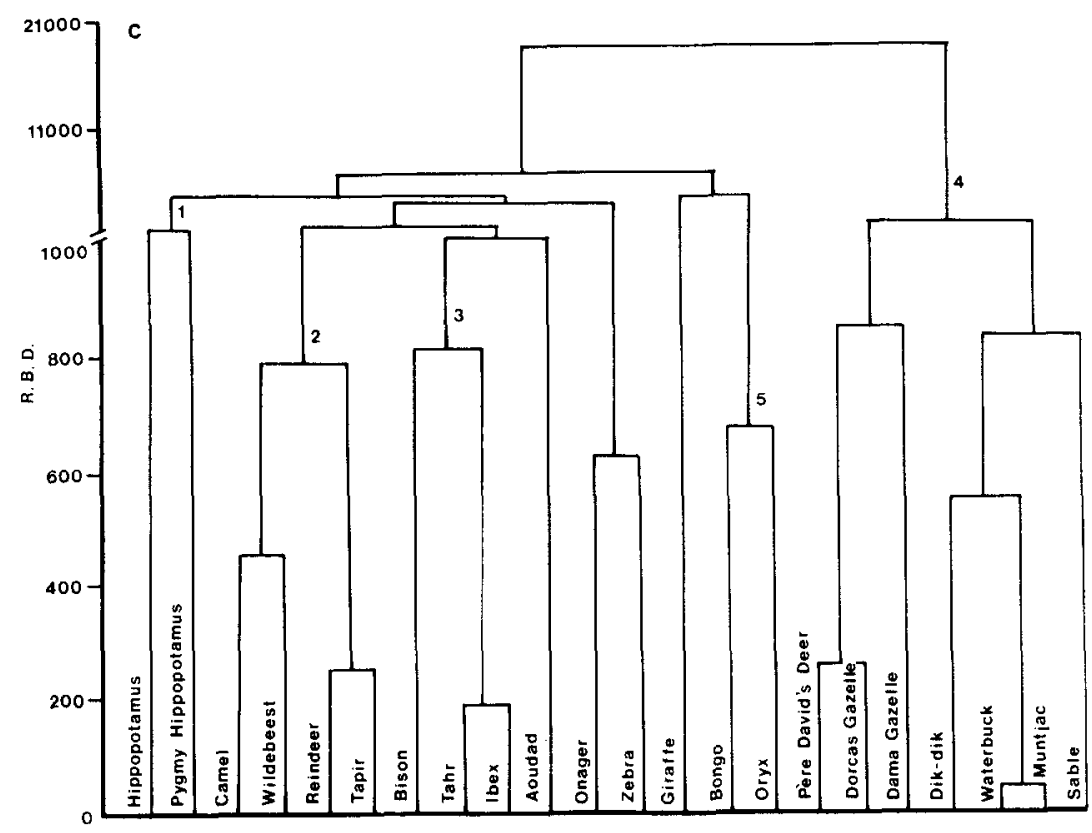

Figure 2c.

Figure 2. Cluster analyses of data for all species using various combinations of measures: (a) <1 ML. Walther's measure and Contact; (b) these three measures plus MCA index; and (c) these four measures plus Young Lying. Cophenetic correlations $=0.7416,0.7571$ and 0.7491 , respectively.

sample sizes and our analyses placed all three in the 'strong' hider group, in agreement with field observations (Table V). Furthermore, data on two pairs of the same species never differed to the extent that our classification as follower or hider would have changed had we been able to observe only one of the pairs.

Differences in enclosure size and design, and the extent to which observation periods coincided with the activity periods of different species may have influenced our results in unknown ways. The only species observed in both a small (0.13 ha) and a large ( $12 \cdot 14$ ha) enclosure was the oryx; we did not detect any obvious differences on our measures between animals from these two enclosures.

We believe that the main effect of differences in enclosure design was on the percentage of time that both mother and young were visible, which tended to be lower in enclosures where the animals were able to move out of view. Although abundant cover in an enclosure made it difficult at times for an observer to locate the young, it is unlikely that the availability of cover affected the amount of time young of hider species spent 'hiding'. Young of these species typically hide (i.e. lie motionless at a considerable distance from the mother) almost all the time in the first days after birth (Lent 1974), and we and others (Walther 1979) have observed that they will hide even if little or no cover is available.

Most species tended to be more active in the morning and late afternoon than during mid-day and our observation periods agreed roughly with these periods of increased activity. The most nocturnal species were probably the Nile hippopotamus, pygmy hippopotamus and tapir. In the wild, the Nile hippopotamus remains close to her young in the water during the day in the early weeks, but leaves it behind while she feeds on land at night ( $\mathrm{H}$. Klingel, personal communication). Such a marked day-night difference in the spatial relationship between mother and young has not been reported in any other ungulate species. The pygmy hippopotamus apparently leaves her young alone in the water at times, but it is not known if this occurs mostly at night (Galat-Luong 1981). Very little is known about mother-young relationships in tapirs, but the young have a disruptively patterned pelage, which suggests that they are hiders (Schürer 1976). Because mother and young were usually resting in close proximity during our daytime observations, all three of these species clustered with the followers (Fig. 2a, b, c). It may be 
Table V. Type of mother-young relationship found in this study and reported in the literature for each species

\begin{tabular}{|c|c|c|c|}
\hline Taxon & $\begin{array}{l}\text { This } \\
\text { study }\end{array}$ & Literature & References \\
\hline \multicolumn{4}{|l|}{ Equidae } \\
\hline $\begin{array}{l}\text { Equus burchelli } \\
\text { (zebra) }\end{array}$ & $\mathrm{F}$ & $\mathrm{F}$ & Klingel $(1969 a, b)$ \\
\hline $\begin{array}{l}\text { Equus hemionus } \\
\text { (onager) }\end{array}$ & $\mathrm{F}$ & $F ?$ & Klingel (1977) \\
\hline \multicolumn{4}{|l|}{ Tapiridae } \\
\hline $\begin{array}{l}\text { Tapirus terrestris } \\
\text { (tapir) }\end{array}$ & $\mathrm{F}$ & $?$ & Terwilliger (1978) \\
\hline \multicolumn{4}{|l|}{ Hippopotamidae } \\
\hline $\begin{array}{l}\text { Hippopotamus amphibius } \\
\text { (Nile hippopotamus) }\end{array}$ & $\mathrm{F}$ & $?$ & Greasley (1973) \\
\hline $\begin{array}{l}\text { Choeropsis liberiensis } \\
\text { (pygmy hippopotamus) }\end{array}$ & $\mathrm{F}$ & $?$ & Galat-Luong (1981) \\
\hline \multicolumn{4}{|l|}{ Camelidae } \\
\hline $\begin{array}{l}\text { Camelus bactrianus } \\
\text { (bactrian camel) }\end{array}$ & $\mathrm{F}$ & $F ?$ & Gauthier-Pilters \& Dagg (1981) \\
\hline \multicolumn{4}{|l|}{ Cervidae } \\
\hline $\begin{array}{l}\text { Muntiacus reevesi } \\
\text { (muntjac) }\end{array}$ & $\mathrm{H}$ & $\mathrm{H}$ & Yahner (1978) \\
\hline Elaphurus davidianus & $\mathrm{H}$ & $F ?$ & Altmann \& Scheel (1980) \\
\hline (Père David's deer) & & $\mathrm{H}$ & Wemmer (1983) \\
\hline $\begin{array}{l}\text { Rangifer tarandus } \\
\text { (reindeer) }\end{array}$ & $\mathbf{F}$ & $\mathrm{F}$ & Espmark (1971) \\
\hline \multicolumn{4}{|l|}{ Giraffidae } \\
\hline $\begin{array}{l}\text { Giraffa camelopardalis } \\
\text { (giraffe) }\end{array}$ & $\mathrm{H}$ & I & $\begin{array}{l}\text { Leuthold (1977) } \\
\text { Langman (1977); } \\
\text { Pratt \& Anderson (1979) }\end{array}$ \\
\hline \multicolumn{4}{|l|}{ Bovidae } \\
\hline $\begin{array}{l}\text { Tragelaphus eurycerus } \\
\text { (bongo) }\end{array}$ & $\mathrm{H}$ & $\mathbf{H}$ & Hamann (1979) \\
\hline $\begin{array}{l}\text { Bison bison } \\
\text { (wood bison) }\end{array}$ & $\mathrm{F}$ & $\mathrm{F}$ & McHugh (1958) \\
\hline $\begin{array}{l}\text { Kobus ellipsiprymnus } \\
\text { (waterbuck) }\end{array}$ & $\mathrm{H}$ & $\mathrm{H}$ & Kiley-Worthington (1965) \\
\hline $\begin{array}{l}\text { Hippotragus niger } \\
\text { (sable) }\end{array}$ & $\mathrm{H}$ & $\mathbf{H}$ & Grobler (1974) \\
\hline $\begin{array}{l}\text { Oryx dammah } \\
\text { (scimitar-horned oryx) }\end{array}$ & $\mathrm{H}$ & $\mathbf{H}$ & Walther (I979) \\
\hline $\begin{array}{l}\text { Connochaetes taurinus } \\
\text { (wildebeest) }\end{array}$ & $\mathrm{F}$ & $\mathrm{F}$ & Estes \& Estes ( 1979) \\
\hline $\begin{array}{l}\text { Madoqua kirki } \\
\text { (dik-dik) }\end{array}$ & $\mathrm{H}$ & $\mathbf{H}$ & $\begin{array}{l}\text { Hendrichs \& Hendrichs (1971) } \\
\text { Bowker (1977) }\end{array}$ \\
\hline $\begin{array}{l}\text { Gazella dorcas } \\
\text { (Dorcas gazelle) }\end{array}$ & $\mathrm{H}$ & $\mathrm{H}$ & Walther $(1966,1979)$ \\
\hline $\begin{array}{l}\text { Gazella dama } \\
\text { (dama gazelle) }\end{array}$ & $\mathrm{H}$ & $\mathrm{H}$ & Walther (1979) \\
\hline $\begin{array}{l}\text { Hemitragus jemlahicus } \\
\text { (Himalyan tahr) }\end{array}$ & $\mathbf{F}$ & I & Schaller (1977) \\
\hline Capra ibex & $\mathrm{F}$ & I & Schaller (1977) \\
\hline (Kuban ibex) & & $\mathrm{F}$ & Walther (1979) \\
\hline Ammotragus lervia & $\mathrm{F}$ & I & Schaller (1977) \\
\hline (aoudad) & & $\mathrm{F}$ & Haas (1958) \\
\hline
\end{tabular}

F: Follower; H: Hider; I: Intermediate. 
that maternal behaviour in these species actually resembles that of oryx and bongo; the mother sometimes rests close to the young but leaves it alone when she forages.

\section{The Complexity of Mother-young Relationships in Ungulates}

Given the diversity in mother-young relationships documented in this study, it seems appropriate to ask whether the traditional division of ungulate species into followers and hiders is adequate and whether a modification of this system or some other classification would prove more useful.

\section{Bovids}

When only the bovids are considered, the classification of species as either followers or hiders seems reasonable, particularly if each of these two groups is subdivided as Walther (1979) suggests. Walther states that the species within a genus usually have similar patterns of mother-young behaviour and he assigns many bovid genera to one of four categories: strong follower, weak follower, strong hider or weak hider.

Those species in our study scoring $100 \%$ on Walther's measure (wildebeest and aoudad) might be regarded as the strong followers and those scoring $0 \%$ (dama and Dorcas gazelles, dik-dik, sable and waterbuck) as strong hiders (Table II). The cluster diagram (Fig. 1) contains the same strong follower and hider groups. This classification agrees with Walther (1979), except that aoudad (Ammotragus) and waterbuck (Kobus) are placed in the strong rather than the corresponding weak subcategory.

Five of the bovid species in our study had intermediate scores (between 0 and 100) on Walther's measure. In the cluster analysis, three of these, bison, tahr and ibex, associated with the strong followers and the other two, bongo and oryx, with the strong hiders. We tentatively label these groups the weak followers and weak hiders, respectively. This is in accordance with Walther (1979), except that we place the bongo (Tragelaphus) into the weak rather than the strong hider category.

\section{All species}

If the two large clusters in Fig. $2 \mathrm{a}$ are considered to represent the followers and hiders, our classification is in near perfect agreement with the literature (Table V). This simple dichotomous classification, however, obscures the considerable variation in mother-young behaviour among the species within each group (Table II).

Among the followers, the two hippopotamus species displayed a distinct behavioural pattern with very close mother-young association and low activity levels. The two equid species, zebra and onager, scored high on the four measures of association, but the young spent considerably less time lying down than those of other followers (Table II). As a result, the onager and zebra clustered with the followers when only measures of association were considered (Fig. 2a, b), but formed a separate cluster when Young Lying was included as a variable (Fig. 2c).

Young giraffe showed a unique pattern; they were intermediate between followers and hiders with respect to $<1 \mathrm{ML}$, but spent less time lying than the young of any other species except zebra (Table II). Giraffe, therefore, have a different group association in each of the cluster analyses. Depending on which combination of behavioural measures was considered, they were weakly associated with the bovid followers (Fig. 2c), with the bovid hiders (Fig. 2a) or in an intermediate cluster (Fig. 2b). This unusual combination of characteristics may explain conflicting comments about giraffe in the literature (Table V).

The behaviour of the weak bovid hiders. bongo and oryx, was unusual in that a mother often rested close to her young although she left it alone for extended periods. Stringham (1974) found a similar behavioural pattern in the moose (Alces alces), and suggested three types of mother-young relationships in cervids: followers, hiders and 'defenders'. Defenders, such as moose, may leave the young alone while foraging but rest close to and defend it at other times. Both bongo and oryx possess exceptionally large horns and the tendency for females to protect their calves is striking. During our study, one female oryx with a small calf broke her horns attempting to attack an escaped cheetah through the fence of her enclosure.

Although we agree with Stringham's view that the extent to which the mother can and will protect her young is an important dimension to consider in cross-species comparisons of mother-young relationships in ungulates, we doubt that his three-way classification can be successfully extended from cervids to ungulates as a whole. He suggests that followers cope with predators by flight, hiders by concealment, and defenders through defence. However, followers such as bison may defend their 
young vigorously either alone or as part of a social group. Furthermore, many ungulate species which might be considered behaviourally intermediate between followers and hiders cannot be characterized as showing a high level of maternal defence. The species in the 'intermediate' cluster (Fig. 2b) (bongo, oryx, bison, giraffe, tahr, ibex and aoudad) form a heterogeneous group. Bongo and oryx tend to cluster with the hiders because the mothers often graze at considerable distances from their young, while the bison tends to cluster with the followers because a close association between mother and young is maintained regardless of activity state. The giraffe, as previously noted, shows its own unique combination of behavioural traits. The goats and sheep, tahr, ibex and aoudad, may form another distinct group. Schaller (1977) suggests that most sheep (Ovibovini) and goats (Caprini) are characterized by very short hiding periods and subsequent following of the mother by the young. We suspect this is true in some species even though we did not detect a distinct shift from hiding to following in those we observed.

In summary, we conclude that the traditional follower-hider dichotomy, although useful as a rough characterization of mother-young relationships in many ungulates, does not adequately describe the entire range of behavioural variation in these relationships. A modification of this classification, such as the division of each major category into weak and strong categories, may prove helpful for some groups. However, a far more informative representation of similarities and differences among species can be attained by using numerical scores on standardized measures.

In general, it has been difficult to combine and compare results of past studies on mother-young behaviour in ungulates because data have been collected in different ways by different observers. We believe that our five behavioural measures provide a reasonably good basis for characterizing mother-young relationships in ungulate species. By using standardized quantitative measures such as these, future investigators should be able to resolve apparent contradictions and to integrate newly studied species into the framework established by our study.

\section{ACKNOWLEDGMENTS}

This project would not have been possible without the help of the Friends of the National Zoo, Washington, D.C., who provided many of the volunteer observers as well as financial support. We thank L. W. Cahill, director of live collections at MTZ, for facilitating observations there and LeeAnn Hayek and James Craig for help with the statistical analysis. We are very grateful to all those who observed animals or helped in other ways at NZP and MTZ and regret that space does not allow us to recognize them individually.

\section{REFERENCES}

Altmann, D. \& Scheel, H. 1980. Geburt, Beginn des Sozialverhaltens und erstes Lernen beim Milu, Elaphus davidianus. Milu., 5, 146-156.

Bowker, M. H. 1977. Behavior of Kirk"s dik-dik (Madoqua kirki hindei) in Kenya. Ph.D. thesis, Northern Arizona University.

Espmark, Y. 1971. Mother-young relationship and ontogeny of behavior in reindeer (Rangifer tarandus L.). $Z$. Tierpsychol., 29, 42-81.

Estes, R. D. 1976. The significance of breeding synchrony in the wildebeest. E. Afr. Wildl. J., 14, 135 152.

Estes, R. D. \& Estes, R. K. 1979. The birth and survival of wildebeest calves. Z. Tierpsychol., 50, 4595.

Fraser, A. F. 1968. Reproductive Behaviour in Ungulates. London: Academic Press.

Galat-Luong, A. 1981. Quelques observations sur un hippopotame pygmée nouveau-né (Choeropsis liberiensis) en forêt de Taï, Côte d'Ivoire. Mammalia, 45, 3941.

Gauthier-Pilters, H. \& Dagg, A. I. 1981. The Camel: Its Evolution, Ecology, Behavior, and Relationship to Man. Chicago: University of Chicago Press.

Greasley, W. H. 1973. Protective maternal behavior of hippopotamus. Puku, 7, 196.

Grobler, J. H. 1974. Aspects of the biology, population ecology, and behavior of the sable Hippotragus niger niger (Harris, 1838) in the Rhodes Matapos National Park, Rhodesia. Arnoldia (Rhodesia), 7, 1-36.

Haas, G. 1958. Untersuchungen über angeborene Verhaltensweisen bei Mähnenspringern (Ammotragus lerria Pallas). Z. Tierpsychol., 16, 218-242.

Hamann, U. 1979. Beobachtungen zum Verhalten von Bongos (Tragelaphus ervceros Ogilby 1836) im Frankfurter Zoo. Zool. Gart., 49, 319-375.

Hendrichs, H. \& Hendrichs, U. 1971. Freilanduntersuchungen zur Ökologie und Ethologie der ZwergAntilope Madoqua (Rhynchotragus) kirki (Gunter, 1880) In: Dik-Dik und Elefanten (Ed. by H. Hendrichs \& U. Hendrichs), pp. 9-75. Munich: Piper.

Kiley-Worthington. I. 1965. The waterbuck (Kobus defassa Ruppel 1835 and $K$. ellipsiprymnus Ogilby 1833) in East Africa: spatial distribution. A study of sexual behavior. Mammalia, 29, 177-204.

Klingel, H. 1969a. Reproduction in the plains zebra, Equus burchelli boehmii: behavior and ecological factors. J. Reprod. Fert., Suppl., 6, 339-345. 
$\mathrm{K}$ lingel, H. 1969b. The social organization and population ecology of the plains zebra (Equus quagga). Zool. Afr. 4, 249-263.

Klingel, H. 1977. Observations on social organization and behaviour of African and Asiatic wild asses (Equus. africanus and E. hemionus). Z. Tierpsychol., 44, 323331

Langman, V. A. 1977. Cow-calf relationships in giraffe (Giraffa camelopardalis giraffa). Z. Tierpsychol. 43, 264-286.

Lent, P. C. 1974. Mother-infant relationships in ungulates. In: The Behatior of Ungulates and Iis Relation to Management (Ed. by V. Geist \& F. Walther), pp. 1455. Morges, Switzerland: International Union for the Conservation of Nature and Natural Resources.

Leuthold, W. 1977. African Ungulates: A Comparatice Retiew of their Ethology and Behatioral Ecology. New York: Springer-Verlag.

McHugh. T. [958. Social behavior of the American buffalo (Bison hison hison). Zoologica, 43, 1-40.

Murdock, G. K., Stine, W. W. \& Maple, T. L. 1983 Observations of maternal-infant interactions in a captive herd of sable antelope (Hippotragus niger). Zool Biol.. 2, 215224.

Pratt, D. M. \& Anderson, V. H. 1979. Giraffe cow calf relationships and social development of the calf in the Serengeti. Z. Tierpsychol. 51, 233-251.

Ralls, K. Lundrigan, B. \& Kranz, K. 1983. Variability of behavioral data recorded by volunteer observers. $\mathrm{Int}$. Zoo Ybk. 22, 244249.

Schaller. G. B. 1977. Mountain Monarchs. Chicago: University of Chicago Press.

Schürer. U. 1976. Beobachtungen an einem neugeborenen Flachlandtapir, Tapirts terrestris (Linne 1766). Zool. Gart. 46, 367-370.

Sokal. R. 1961. Distance as a measure of taxonomic similarity. Sist. Zool.. 10, $70 \cdots 76$.
Stringham, S. F. 1974. Mother-infant relationships in moose. Nat. Can., 101, 325369.

Talbot. L. M., Payne. W. J. A., Leger, H. P.. Verdcourt. L. D. \& Talbot, M. H. 1965. The meat production potential of wild animals in Africa. Commonn. Bur. Anim. Breed. Genet., 16.

Terwilliger, V. J. 1978. Natural history of Baird's tapir on Barro Colorado Island, Panama, Canal Zone. Biotrepica, 10, 2112230.

Walther, F. 1961. Einige Verhaltensbeobachtungen an Bergwild des Georg von Opel Freigehege. Tierforschung, 1960-1961, 53-89.

Walther, F. 1964. Verhaltensstudien an der Gattung Tragelaphus de Blainville (1816) in Gefangenschaft unter besonderer Berücksichtigung des Sozialverhaltens. Z. Tierpsychol., 21, 393467.

Walther, F. 1965. Verhaltensstudien an der Grantsgazelle (Gazella granti Brooke, 1872) im Ngorongoro-Krater. Z. Tierpsychol., 22, 167208.

Walther, F. 1966. Mit Horn und Huf. Berlin: Paul Parey Verlag.

Walther, F. 1979. Das Verhalten der Hornträger (Bovidae). Handh. Zool., Band 8, Lieferung 54. 10(30). I 184.

Wemmer, C. 1983. Sociology and management. In: The Biology of an Extinct Species: Père David's Deer (Ed. by B. Beck \& C. Wemmer) pp. 126-132. Park Ridge. New Jersey: Noyes.

Yahner, R. H. 1978. Some features of mother young relationships in Reeve's muntjac (Muntiacus rectesi). Appl. Anim. Ethol.. 4, 379-388.

(Received II September 1984; revised 27 December 1984. MS. number: 44190 